\title{
MONUMENTS AND COMMEMORATIONS: A CONSIDERATION
}

\author{
PAUL A. PICKERING \& ROBYN WESTCOTT
}

W hen William Charles Wentworth, the leading conservative politician in the colony of New South Wales, retired from public life in order to travel to Britain in 1853, he informed his devoted followers that he would 'accept no testimonial except in the form of a colossal statue of his person to be placed in some very conspicuous part of Sydney'. According to the report in a hostile newspaper, Wentworth issued this demand so that 'his countrymen might have an opportunity of perceiving how a grateful community could appreciate, reward and honour the services of any individual who devoted sincerely his talents and his leisure to the services of his fellow citizens'. 'It is really a debasement and a degradation for any community claiming to be of British origin and descent', commented the editor of the colony's only Chartist newspaper, 'to be called on to erect a monument for a tyrant slave-monger, a foul-mouthed declaimer; at one time a rebel to the government, and at another time a sycophant and a government crawler'.2

Wentworth's supporters too shied away from the idea of a 'colossal statue' that might glower over the city in perpetuity and they decided, instead, to endow a chair in Wentworth's name at the recently established University of
Sydney. The irascible colonist, however, was actually more in touch with the trend in the wider British world than either his opponents or his supporters. After all, it had only been three years previously that The Times had declared that Britain was in the grip of 'Monument Mania'. ${ }^{3}$ Referring to the capital in particular, the conservative Examiner had similarly worried that statues were 'now rising in every quarter of our metropolis' ${ }^{4}$ The proliferation of 'sacro-secular' sites in the public sphere was debated in parliament and the columns of the press, as well as in lecture rooms, church halls, coffee houses and pubs; it caught the imagination of artists from scurrilous caricaturists to eminent sculptors; and it exercised the minds of some of the great thinkers of the day. ${ }^{5}$

None greater than Jeremy Bentham. It is well known that in 1769, at the age of twenty-one, Bentham decided to leave his body to science. At a time when a widespread fear of dissection and legal impediments denied surgeons corpses for study, Bentham's gesture of rationalist faith was intended as both a contribution to anatomical science in an ethereal sense and as an attempt to sway public opinion. According to his own account, however, the subject of his own death was a 'favourite' at Bentham's table for 'many years' afterwards, and, by the early 1830s 
he had imagined his fate beyond the surgeon's knife on the cold dissection table. 'I have disposed of my own body after death', he boasted, and by 'that disposal I shall have made to the fund of human happiness a contribution, more or less considerable' ${ }^{6}{ }^{6}$

Bentham's final instructions for the treatment of his mortal remains represent the ne plus ultra (or perhaps the reductio ad absurdum) of the utilitarian system of philosophy that he founded. Three days after his death in June 1832, in accordance with his instructions, an anatomical oration was given over Bentham's corpse by his friend, Southwood Smith, at the Webb Street School of Anatomy in London. In the audience to witness the dissection of the great philosopher were students, disciples, friends and philosophical luminaries such as James Mill (father of John Stuart) and Lord Brougham, the father of the Mechanics' Institute movement. Smith's lecture was rushed into print as a seventy-three page pamphlet replete with a lithograph of the prostrate corpse on the cover. ${ }^{7}$

Following the dissection, Bentham's bones were re-assembled to make a skeleton that could be posed 'in such a manner as that the whole figure may be seated in a Chair usually occupied by me when living in the attitude in which I am sitting when engaged in thought'. According to his wishes, the skeleton was dressed in one of Bentham's black suits, stuffed with straw and sealed in a display case. Bentham's head had been preserved 'untouched' in an air-tight jar, but having lost its expression, a wax model was commissioned from a noted French artist, Jacques Tarlich. The wax head was added to the skeleton to complete what Bentham himself had called his 'Auto-Icon'. In this way, he wrote, he would become 'his own image'. $^{8}$

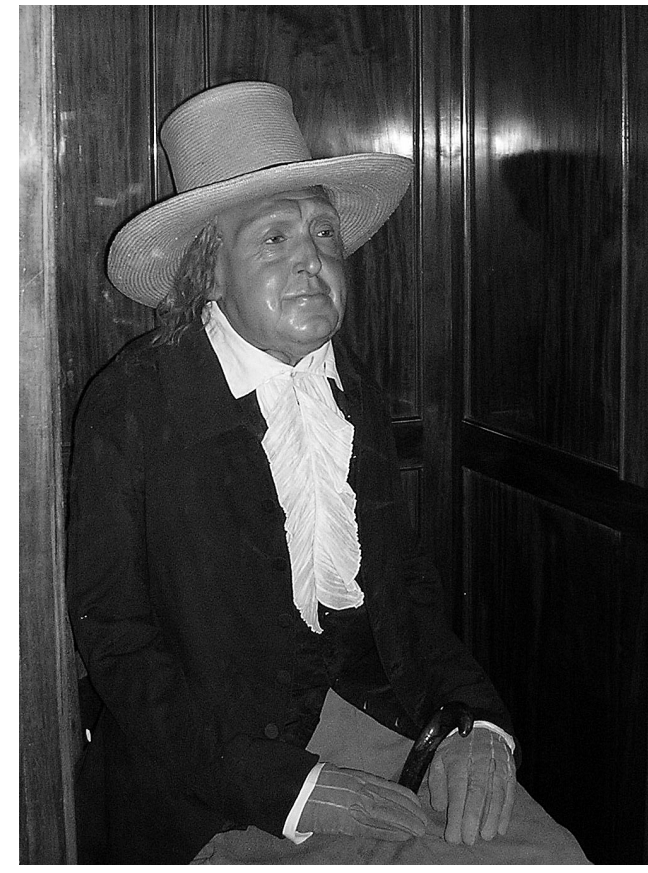

Jeremy Bentham's 'Auto-Icon', University College London. Source: Photograph 2003

Visitors to University College London today can see Bentham's Auto-Icon sitting in its display case, cane in hand, yellow straw hat upon its wax head, his gaze fixed in eternal contemplation. The jar containing his head, with its unearthly visage, is never far away - often it is placed on the floor between his feet except when it is taken to occupy pride of place at University meetings and undergraduate ceremonies. Bentham wanted it that way, as his Will made clear: 'If it should so happen that my personal friends and other Disciples should be disposed to meet together on some day or days of the year for the purpose of commemorating the Founder of the greatest happiness system of morals and legislation', then the Auto-Icon should be brought to the room. ${ }^{9}$ When 'Bentham has ceased to live', he mused, 'whom shall the Bentham Club have for its chairman? Whom but Bentham himself? On him will 
all eyes be turned - to him will all speeches be addressed'. ${ }^{10}$

What might ostensibly seem like a macabre self-indulgence was, in fact, part of an elaborate plan for a national system of education and commemoration. This is not well known. Bentham's last unpublished - tract, Auto-Icon, Or, Farther Uses of the Dead for the Living, penned shortly before his death in 1832, was nothing less than a manifesto for the age of monuments. Although exhibitions of wax figures were not new - Madame Tussaud had been touring Britain with a collection of wax models since 1802 and Bentham was aware of other wax museums in London ${ }^{11}$ - galleries of 'Auto-Icons' (he did not envisage the need for wax heads) went far beyond anything then in existence, either in Britain or on the continent.

Bentham's vision was breathtaking in its scope. The benefits of Auto-Icons, Bentham enthused, ranged from moral, political and honorific, to commemorational, genealogical and phrenological. Soon statues of stone and marble, as well as grave yards filled with dangerously unhealthy corpses, would be things of the past. Education was never far from Bentham's considerations. Lords, Spiritual and Temporal, 'in their AutoIcon state', 'their robes on their back their coronets on their head', would be displayed 'in their own most Honourable House'. History might be 'forged', but not Auto-Icons, the truth of the past ever present among the living. 'Out of AutoIcons, a selection might be made for a Temple of Fame', he continued, 'a temple with a population of illustrious AutoIcons'. 'In every church - in every chapel - in a word, in every repository for the Auto-Iconized dead, a phrenologist would behold a lecture-room, replete with subjects for the anatomico-moral instruction which it belongs to him to administer'. The Auto-Icons of the virtuous, Bentham argued, would 'set curiosity in motion, virtuous curiosity': 'There would be pilgrimages to AutoIcons, who had been living benefactors of the human race - not to see miracles not for the purposes of imposture - but to gather from the study of individuals, benefits for mankind' ${ }^{12}$

Recognising the spirit of the age, Bentham was clear that the manufacture of Auto-Icons should be an act of egalitarianism. 'So now may every man be his own statue', Bentham wrote, even if this necessitated public funding. 'If, at common expense poor and rich were Iconized, the beautiful commandment of Jesus would be obeyed; they would indeed "meet together", they would be placed on the same level'. ${ }^{13}$ Nor would the galleries of figures be the exclusive preserve of men; Bentham imagined Auto-Icons of the two sexes 'alternating with one another'.

Even if Bentham had lived long enough to published his pamphlet and to commence a public agitation in favour of its contents, it is doubtful that the idea of Auto-Icons would have caught the public imagination. Some of his 'disciples' were uncomfortable with his plans for his own remains, let alone supportive of the practise as a social system. The age of monuments was unlikely to have become the age of Auto-Icons. Nevertheless, Madame Tussaud's gallery of wax figures, dressed as they would have appeared in life, was transformed in the years following Bentham's death from a travelling side-show curiosity to a major cultural industry that combined commemoration and entertainment. After moving to premises in Baker Street in 1835 Tussaud's gallery quickly became a popular London attraction. As early as 
1842 one commentator suggested that Tussaud had amassed a fortune 'upon common sympathies': 'thousands crowd her rooms; princes, merchants, priests, scholars, peasants, schoolboys, babies, in one common medley'. By 1859, according to Dickens, Tussaud's had become 'something more than an exhibition; it is an institution'. ${ }^{14}$

As the contributions to this special issue of Humanities Research make clear, the study of monuments and commemorations is increasingly finding its way onto the agenda of social historians, taking its place as part of the burgeoning field of 'memory studies'. Nevertheless, the study of monuments tends to be energised primarily in the moment of empirical engagement, in teasing out the inter-relation between the monument and the historical context in which it is embedded. Although theory has sometimes helped to illuminate this task, an attempt to produce a theoretically-based analysis of monuments has not tended to be seen as an interesting task in and of itself. Reflecting on the weevil-infested corpse in University College London a number of theoretical issues can at least be placed on the table.

In a essay entitled 'Present Pasts: Media, Politics, Amnesia', Andreas Huyssen explores the compulsion to remember in recent academic work and invites consideration of the notion of 'selfmusealization'. Arguing that this drive to produce 'mnemohistory' ${ }^{15}$ constitutes a significant deviation from the modernist agenda which privileged a teleological pursuit of the future, Huyssen problematises any easy positioning of the past as a repository of recoverable meaning. ${ }^{16}$ Memory, he asserts, is intimately connected to cultural and psychic processes that threaten to overwrite remembering with forgetting, and entangle both inclinations with imaginative recreations of the past that are neither politically or commercially disinterested. ${ }^{17}$ 'Self-musealization' - a term worthy of Bentham himself - is discussed as a response to postmodern indeterminacy whereby an individual strives to acquire a degree of ontological stability through the conscious positioning of him/herself as an archive. 'Musealization', the extension of institutional practices of collecting and collating to artefacts and behaviours located in the quotidian, was first proposed by the German philosopher Hermann Lübbe more than two decades ago. ${ }^{18}$ Lübbe posited that this fetishization of the past evidenced in acts of musealization compensated for 'the atrophy of valid traditions, the loss of rationality, and the entropy of stable and lasting life experiences' that had accompanied the collapse of the Enlightenment project after Auschwitz. ${ }^{19}$ Thus, the subject's experience of the present (circa 1983) was conditioned by the production of ever tightening cycles of 'innovation' and 'obsolescence' that effected a contraction of the synchronic, thus 'shrinking the chronological expanse of what can be considered the (cutting edge) present at any given time' ${ }^{20}$

The addition of the prefix 'self' to Lübbe's conception is Huyssen's innovation. 'Self-musealization' is presented as a millennial phenomena, enabled by technological advances such as the video camera, but accompanied by a resurgence of interest in its historical precedents, 'memoir writing and confessional literature'. ${ }^{21}$ This co-option of memory work into the private domain (and the implicit suggestion that the cultural productions of an 'unmarked' individual could conceivably be regarded as deserving of the 'material per- 
sistence $^{22}$ accorded to monuments occupying civic space) is related by Huyssen to the emergence of what German sociologists have termed the Erlebnisgsellschaft or, literally, 'society of experience' ${ }^{23}$ A society of experience 'privileges intense but superficial experiences oriented toward instant happiness in the present and quick consumption of goods, cultural events and mass-marketed lifestyles' ${ }^{24}$ Surely a parallel can be invoked between the rise of 'self-musealization' in the face of the exigencies of the postmodern world and the historical circumstances in which Bentham conceived of the Auto-Icon. In both cases, the air was charged with the possibility and uncertainty generated by rapid socio-economic and political change.

Intrinsically monuments, at least in the eyes of some of those who petition for, finance or create them, are designed to last: they are meant to be permanent statements of a particular nexus in the narrative of a nation, a community or a cause. Their ostensible permanence inevitably stands in contradistinction to other, more spontaneous, forms of commemoration: ephemeral scatterings of candles and flowers; the impromptu wash of crowds through public spaces; or the apparent candour of events archived through the lens of modern photojournalism. Realising what Michael Garval has called the 'rêve de pierre' or 'dream of stone', ${ }^{25}$ a monument bulwarks the temporal mutability of spoken rituals - staying the breath in which an oath is uttered, fixing citations of praise and remembrance, reiterating the consecration of the dead. This rendering of the past as ambient authorises the continuous resolution of moral and cultural ambiguities that might potentially destabilise hegemonic discourses of national or community cohesion. Such continuity is, however, produced at the expense of inclusive representation. Any metanarrative of group experience is enabled only through the artificial erasure of radical social, political or cultural schisms. Although Bentham conceived of Auto-Iconography as initiating a civic project combining both education and commemoration that was innately inclusive, it is hard to see how it might have worked in practice. Indeed it is well nigh impossible to think of a monument that is beyond criticism for being partial if not partisan. For example, critics have pointed out that the Lincoln Memorial in Washington makes no reference, artistic or textual, to either slavery or secession. ${ }^{26}$ The Vietnam Veterans' Memorial, also situated on the Mall in Washington, has a mandate that prohibits the individual citation of those servicemen who died outside the theatre of engagement in South-East Asia. Thus veterans who later succumbed to the effects of Agent Orange or, devastated by post-traumatic stress disorder, took their own lives are not accorded recognition equivalent to that extended to combat victims. ${ }^{27}$ Similarly, the US-based AIDS Memorial Quilt Project has attracted criticism from interest groups for variously: privileging the experience of loss and mourning in the gay community; failing in its assumed didactic function of educating communities about the prevention of HIV transmission, ${ }^{28}$ and, in a final irony, for becoming 'de-gay[ed]' as a result of the extension of the project to 'accommodate racial and sexual diversity'. ${ }^{29}$

Bentham's assertion that the AutoIcon's would 'set curiosity in motion, virtuous curiosity', was based on the idea that Auto-Icons would initiate and ultimately be accessed through a process 
of constructive engagement with their audience. As these examples show, erecting monuments to perform the civic work of thinking is problematic. Steven Johnson notes a paradox fundamental to the pedagogical or didactic function related to monuments - that in the very act of concretising, and therefore 'eternalising', a particular truth (not an unproblematic notion), the citizen-viewer is removed from the requirement that $\mathrm{s} /$ he understand the social or political flux that produced it. Johnson argues that the decoupling of historical processes from commemorative outcomes has rendered monuments 'self-defeating' to the point of 'inhibit[ing] the formation of the ethic they are meant to induce' ${ }^{30}$ This is reminiscent of Robert Musil's blunt conclusion that a statue is a 'carefully calculated insult' to its subject: 'there is nothing in this world as invisible as a monument'. ${ }^{31}$ Johnson further contends that most forms of public memorialisation stand in for 'the civic work that only citizens themselves can do to lasting effect' $^{\prime}{ }^{32}$ A monument can only ever be supplementary to the complexities of the historical circumstance that gave rise to it. It can never substitute for them. This is of particular significance in an era where fictive recreations of historical events are more easily accessed by a mass audience than primary or secondary source materials. This has led, for example, to the commissioning of a recent statute at the William Wallace Monument in Scotland that takes as its primary reference Mel Gibson's depiction of Wallace in the film Braveheart. ${ }^{33}$ If the Bentham's Auto-Icon was the reductio ad absurdum of utilitarianism, a Gibson-like Wallace is surely the ne plus ultra of postmodernism. As Jean Baudrillard has written of simulacra, 'It is no longer a question of imitation, nor of reduplication, nor even of parody'. 'It is rather', he continued, 'a question of substituting signs of the real for the real itself; that is, an operation to deter every real process by an operational double, a metastable, programmatic, perfect descriptive machine which provides all the signs of the real and short-circuits all its vicissitudes' ${ }^{34}$ What is really real?

Both the empirical and the theoretical agendas are advanced by the contributions to this special edition of Humanities Research. Marc Serge Rivière gives a detailed account of the monuments to Lapérouse, erected in Mauitius and at Botany Bay, that crossed the boundaries of nationality, war and empire to honour the passion of discovery that united sea-farers. A decade after the end of the long revolutionary wars between France and Britain (and well before the erection of the first official statue in New South Wales in $1842^{35}$ ), Rivière shows that Governor Brisbane not only permitted but actively encouraged the construction of Bougainville's monument to his fellow French explorer at Botany Bay in 1825. Ken Taylor's discussion of one of the wonders of the world, the Candi Borobudur monument in central Java, highlights critical issues of significance, intangible heritage and conservation. The contrast between the venerable spirituality of the monument and the cacophonous bustle and chaos of the surrounding tourist precinct described in this paper is striking and concerning. In her contribution, Ana Carden-Coyne reflects on the embodiment of gender in the memorial architecture of the First World War. By showing how memorials reflect 'wider debates about the status of the returned soldier, as well as women's claims to 
citizenship in postwar societies', CardenCoyne goes beyond the familiar tropes war/death as masculine and peace/ renewal as feminine - to explore gendered architecture in new and subtle ways.

Both Alex Tyrrell and Tony Taylor highlight the ways that commemoration can become the subject of acute political contest. By examining the death and afterlife of Ernest Jones, the last national leader of Britain's Chartist campaign for democratic reform, Taylor traces in crucially important ways what he calls the 'fracture-lines dividing the competing radical and Liberal interpretations of the national narrative of liberty and reform'. This was a contest between sometimes allies and fellow-travellers who were never all that far apart on the spectrum of nineteenth century British politics. The same can not be said of the dispute discussed by Alex Tyrrell. In this wonderful essay we are given a front row seat to a (literally) monumental battle over the fate of a statue to the perpetrator of the Sutherland Clearances in the Scottish Highlands. Following Pierre Nora, Tyrrell points to the advantages of distinguishing between history and public memory as a way of reconceptualising 'history wars' in Scotland and elsewhere. Students of Australia's 'history wars' will learn a lot from this approach. Towards the conclusion of his tract Bentham looked forward to the day when Auto-Icons 'in their silence would be eloquent preachers'. Taken together the contributions to this issue of Humanities Research show that social, cultural and political historians have begun to listen.

\section{ENDNOTES}

1 Wentworth cited in People's Advocate, 24 December 1853.

2 People's Advocate, 31 December 1853.

3 The committee spent $£ 300$ on a portrait but applied the remainder of the subscription ( $£ 2640-17-6 d)$ to the establishment of the chair of 'modern history'. See People's Advocate, 8 September 1855. For 'monument mania' see The Times, 12 August 1850. We are grateful to Alex Tyrrell for this reference.

4 Cited in Glasgow Examiner, 19 October 1850.

5 For a discussion of the rise of 'monument mania' in Britain see Paul A. Pickering and Alex Tyrrell, Contested Sites: Commemoration, Memorial and Popular Politics in Nineteenth Century Britain, Aldershot, 2004.

6 Auto-Icon; Or, Farther Uses of the Dead to the Living. A Fragment. From the Mss. Of Jeremy Bentham [1832], Essen, 1995, p. 14.

7 See C.F.A. Marmoy, 'The Auto-Icon of Jeremy Bentham at University College, London', Medical History, vol. 2, no. 2, April 1958, pp. 77-86 (reproduced on http://www.ucl.ac.uk/BenthamProject/info/marmoy.htm [accessed 19.12.2003]). See also Ruth Richardson, Death, Dissection and the Destitute, London, 1987, pp. 159-60.

8 Bentham, Auto-Icon, p. 16. Bentham's Will is quoted by Marmoy.

9 See Marmoy, 'The Auto-Icon'.

10 Bentham, Auto-Icon, p. 21.

11 E. V. Gatacre, Madame Tussaud's, London, 1977, p. 38, Bentham, Auto-Icon, p. 18. 
12 Bentham, Auto-Icon, passim.

13 Bentham, Auto-Icon, p. 17.

14 Cited in Gatacre, Madame Tussaud's, p. 38.

15 Andreas Huyssen, 'Present Pasts: Media, Politics, Amnesia', Public Culture, vol. 12 no. 1, 2000, p. 33.

16 Huyssen, 'Present Pasts', p. 21.

17 Huyssen, 'Present Pasts', p. 27.

18 Huyssen, 'Present Pasts', p. 32.

19 Huyssen, 'Present Pasts', p. 32.

20 Huyssen, 'Present Pasts', p. 32.

21 Huyssen, 'Present Pasts', p. 24.

22 Hartmut Winkler, 'Discourses. Schemata, Technology, Monuments: Outline for a Theory of Cultural Continuity', Configurations, vol. 10, 2002, p. 95.

23 Huyssen, 'Present Pasts', p. 25.

24 Huyssen, 'Present Pasts', p. 25.

25 Michael Garval, “"A Dream of Stone”: Fame, Vision and the Monument in Nineteenth-Century French Literary Culture', College Literature, vol. 30 no. 2, 2003, p. 83.

26 Steven Johnston, 'Political Not Patriotic: Democracy, Civic Space, and the American Memorial/Monument Complex', Theory and Event [online] vol. 5(2), 2002, paragraph 16. Available from http:/ / muse.jhu.edu/journals/ theory_and_event/v005/ 5.2johnston.html [Accessed 07/03/2004]

27 Johnston, 'Political Not Patriotic', paragraph 39 .

28 Christopher Capozzola, 'A Very American Epidemic: Memory Politics and Identity Politics in the AIDS Memorial Quilt, 1985-1993', Radical History Review, no. 82, Winter 2002, p. 101.

29 Capozzola, 'A Very American Epidemic', p. 100.

30 Johnston, 'Political Not Patriotic', paragraph 19.

31 Cited in Katharine Hodgkin and Susannah Radstone (eds), Contested Pasts: The politics of memory, London, 2003, p. 195.

32 Johnston, 'Political Not Patriotic', paragraph 19.

33 Andrew Ross, 'Wallace's Monument and the Resumption of Scotland', Social Text, vol. 18 no. 4, 2000, p. 101.

34 Jean Baudrillard, Simulacra and Simulation (trans. Sheila Glaser), Ann Arbour, Michigan, 1995, p. 2.

35 See S. K. Inglis, Sacred Places: War Memorials in the Australian Landscape, Melbourne 1998, p. 27. 